\title{
An Alternative Heterogeneous Catalyst Synthesis From Seabass (Dicentrarchus Labrax) Scales for Biodiesel Production
}

Gediz UĞUZ ( $\sim$ gediz.uguz@omu.edu.tr)

Ondokuz Mayis University: Ondokuz Mayis Universitesi https://orcid.org/0000-0002-6796-6067

Muntadher Musafer Obaid Alwahidhawi

Ondokuz Mayis University: Ondokuz Mayis Universitesi

\section{Research Article}

Keywords: Biodiesel, Calcination, Dicentrarchus Labrax, Fish scale, Heterogenous catalyst, Seebass, Transesterification

Posted Date: July 8th, 2021

DOI: https://doi.org/10.21203/rs.3.rs-678657/v1

License: (c) (i) This work is licensed under a Creative Commons Attribution 4.0 International License.

Read Full License 


\section{Abstract}

Biodiesel is one of the renewable energy sources derived from living organisms and is an alternative to petroleum fuels that cause environmental pollution. Biodiesel is specified as the fatty acid alkyl esters (FAAE) formed as a result of the transesterification reactions of various alcohols and triglycerides with catalysts. The catalyst plays an important role in biodiesel production. These catalysts can be synthesized from chemical or natural substances as homogeneous or heterogeneous. Some natural waste materials such as egg shell and fish scales have started to be preferred in catalyst synthesis due to their low cost, accessibility and support for waste recycling and minimizing. In this study, a highperformance heterogeneous catalyst was synthesized in order to reduce cost, increase the reaction rate and evaluate waste fish scales in biodiesel production. Waste fish scales were characterized by Thermogravimetric Analysis (TGA). The novel catalyst was prepared from waste Seabass (Dicentrarchus Labrax) fish scales by calcination at different temperatures (800, 900, 950 and $\left.1000{ }^{\circ} \mathrm{C}\right)$. The best calcination temperature was determined by using as X-Ray Diffraction (XRD) techniques as $1000^{\circ} \mathrm{C}$ and the waste fish scale catalyst was shortened as WFSC. The novel WFSC was characterized by BET specific surface area, Scanning Electron Microscopy (SEM) and Fourier Transform Infrared Spectroscopy (FT-IR). Finally, the novel WFSC were used for biodiesel production. Biodiesel yield was calculated as $85 \%$. Additionally, this novel catalyst reduces chemical consumption in biodiesel production, with its reusability. Due to the obtained results, it can be qualified as an eco-friendly catalyst.

\section{Introduction}

Energy, which forms the basis of economic development, is an indispensable part of the life. [1, 2]. With the increase population rate in the world, the demand and dependence on energy is increasing every year compared to the past $[3,4]$. Although fossil fuels such as crude oil $(35 \%)$, coal $(29 \%)$, and natural gas $(24 \%)$ are the main source of the existing energy used from primary fuels, fossil fuels are nuclear $(75 \%)$ and renewable energy sources (5\%) [5]. Primary energy consumption worldwide is expected to grow by $1.6 \%$ annually as compared with today and the next decade. Fossil fuels thus constitute $88 \%$ of the world's supply of oil as the largest source of energy [6]. However, some crises occur due to the depletion of oil resources in the future, the constantly increasing oil prices and the negative effects of fossil fuels on the environment. As a result of these troubles, alternative renewable energy sources have become an important research area. The fact that fossil fuels will run out one day has led researchers to seek new, cleaner alternative fuels such as biodiesel, biomass, wind, hydroelectric and solar [2,7]. The classification of energy resources and renewable energy capacities in today and future were shown in Table 1.

Table 1. Classification of Energy Resources in the world [8, 9]. 


\begin{tabular}{|ll|}
\hline Renewable Energy Sources & Classic Energy Sources \\
\hline Wind power & \\
Biomass energy (Biodiesel, Biogas) & \\
Geothermal energy & Fossil Based Fuels \\
Photovoltaic energy & Nuclear Energy Resources \\
Hydraulic energy & \\
Solar energy & \\
Tidal Energy & \\
\hline
\end{tabular}

As seen in Table 1, the usage of alternative renewable energy sources is in an increasing trend today and in the future. Especially, biomass energy will have gain margin for energy production. Animal and plant origin materials are in the biomass energy resource [10]. Additionally, biodiesel is an alternative fuel which is a sub-subject of biomass energy included in renewable energy sources [8].

Additionally, large-scale fossil fuel burning causes air pollution. In order to prevent this air pollution, researchers and scientists are looking for alternative fuels that have lower emission values when burned than fossil fuels. For biofuel to be an alternative to conventional petroleum diesel: the fuel must be technically suitable, cost-effective, and environmentally safe. The most suitable options for this purpose are vegetable oils, bio-alcoholics, biogas and biodiesel. Biodiesel is commercially marketed as an additional diesel fuel among these alternative fuels $[6,11]$. Biodiesel is made from long-chain fatty acid esters derived from vegetable oils [12].

Biodiesel is an alternative renewable fuel type to conventional fuels (gasoline - diesel - natural gas) that can be used to power a mechanical engine [13]. It is preferred to use it more than other fuels because it is made from renewable materials such as vegetable oils and other materials. Biodiesel saves more than $83 \%$ of emissions compared to conventional fossil fuels $[1,14]$. Biodiesel can be replaced with petroleum in transportation, accumulation of energy and engines. However, currently, biodiesel can only be blended in conventional fuels with legal regulations at a maximum rate of $10 \%$ in Europe by 2020 [14].

Biodiesel is easy-to-use, non-toxic, biodegradable without sulfur or compound perfume, carbon-neutral and environmentally friendly diesel fuel also attracted substantial global interest in reducing global warming and dependency on traditional fossil fuels [4]. Fatty acid alkyl esters (FAAE) (biodiesel) and glycerol are generated as by-products of oil or fat in transesterification with alcohol [15-17] .

Biodiesel is a green low-emission diesel substitute generated from incoming sources and which can be used without modifications in current engines. This is the first domestically manufactured state-of-the-art biofuel available commercially [18]. 
Biodiesel, we have already known that it is a replacement fuel, so it is compatible with the environment and can be degraded in nature in a short period of time (99.5\%). Table.2 shows the comparison of the emissions in the fuels prepared in B20 and B100 ratios $[19,20]$. And since it is considered the low capacity of greenhouse gas emissions of biodiesel compared to fossil fuels is the reason. However, its true proportion depends on many factors. Therefore, an important characteristic of biodiesel is its ability to reduce pollutants such as unburned hydrocarbons, carbon monoxide, and particulate matter emitted from the engine [21].

Table 2. Comparison of Diesel and Biodiesel Emissions (by\%) $[19,20]$.

\begin{tabular}{|lll|}
\hline Emissions & B20 & B100 \\
Carbon monoxide $(\mathrm{CO})$ & -7.00 & -33.00 \\
Particle matter $(\mathrm{PM})$ & -6.50 & -32.50 \\
Sulphur oxides $\left(\mathrm{SO}_{\mathrm{x}}\right)$ & -1.62 & -8.07 \\
Methane $\left(\mathrm{CH}_{4}\right)$ & -0.55 & -3.01 \\
Hydrofluoric acid $(\mathrm{HF})$ & -3.15 & -16.02 \\
Hydrocarbons $\left(\mathrm{C}_{\mathrm{x}} \mathrm{H}_{\mathrm{y}}\right)$ & 8.01 & 37.01 \\
Hydrochloric acid $(\mathrm{HCl})$ & 3.41 & 15.04 \\
\hline
\end{tabular}

The main methods for biodiesel fuel production are heating of vegetable oils, refining, microemulsion, thermal cracking (pyrolysis) and transesterification [22]. Transesterification method is the most common important among these methods (Figure 1). Fatty acid alkyl esters (biodiesel) and glycerol are the byproducts of oils and fats for transesterification by alcohols with catalyst [17].

Enzymatic, non-catalytic, and catalytic approaches have been used to realize the transesterification reactions. Furthermore, the non-catalytic transesterification process was carried out under supercritical conditions [25]. This requires higher, economically viable temperatures and strain. Therefore, the processes of catalytic transesterification are often more are preferable used for biodiesel production [26]. In the literature, the catalysts are classified as of homogeneous and heterogenous types as seen Figure 2 .

Homogeneous catalysis can be simple, enzymatic or acidic, where the necessary catalysis consists of alkaline. In the near foreseeable future, conventional homogeneous catalysts are predicted to be substituted by eco-friendly heterogeneous catalysts. The heterogenous catalysts are easy to recycle and purification [4]. Hence, the improvement of heterogenous solid catalysts has recently come into prominence with increased competition and environmental regulations. Low-cost and most effectively heterogeneous catalysts prepared from waste materials such as eggshell waste [27], oyster shell [28], shrimp shell [29], mud crab shell, mollusk scales [30] and Labeo rohita fish scales [31] have been 
successfully produced to obtain biodiesel. The fish scales have gained importance for synthesis of catalyst because of their as hydroxyapatite (HAP) content.

Hamada and Mikuni (1990) previously showed that the major components of the fish scales as hydroxyapatite (HAP). HAP is formulated as $\left(\mathrm{Ca}_{10}\left(\mathrm{PO}_{4}\right)_{6}(\mathrm{OH})_{2}\right)$ and it can be transformed into $\beta$ tricalcium phosphate $\beta-\mathrm{Ca}_{3}\left(\mathrm{PO}_{4}\right)_{2}$ ( $\beta$-TCP) when calcinated over $600^{\circ} \mathrm{C}$. HAP can be synthesized with calcium oxide $(\mathrm{CaO})$ has and phosphoric acid $\left(\mathrm{H}_{3} \mathrm{PO}_{4}\right)$ reaction as chemically in a laboratory. It can be transformed into $\beta-\mathrm{Ca}_{3}\left(\mathrm{PO}_{4}\right)_{2}$, at around $800-1000{ }^{\circ} \mathrm{C}[31,33]$.

In literature, tri-calcium phosphate (TCP) have been documented as with acidic and basic character [34]. However, the metal phosphates with aluminum, gallium and iron groups are chosen for heterocatalysts preparation. The heterocatalysts are very active, long life and good cross esterification selectivity [35]. Also, the usage of methyl benzoates has also been investigated as a catalyst for transesterification reaction [36].

Seabass (Dicentrarchus labrax) fish scales has ordered three-dimensional structure and highly contain HAP and extracellular matrix and particularly type I collagen fibers. Each fish scale has an outer (bone) layer and an inner fibrillar plate $[37,38]$. Literature data also indicated that upon calcination at $900{ }^{\circ} \mathrm{C}$, the total acidity of HAP decreased from 343 to $81 \mu \mathrm{mol} / \mathrm{g}$; hence, generating an observed base force in calcined HAP [39]. Recently, investigated the use of collagen platelet waste at the fish level to develop a wound dressing material [40]. Additionally, fish scales are using as a source of collagen [41]. The fish scales make up about $6 \%$ of the wet weight of fish $[42,43]$. Although, there are many studies related with fish scales in the literature, not many studies has been published on the usability of calcined fish scales as biodiesel catalysts [31].

The fish scales are a by-product of the aquaculture industry and account for about $30-40 \%$ of the total amount of product. This leads to a huge solid waste problem for companies $[44,45]$. Turkey is the biggest manufacturer of seabass fish and closing the gaps in the fish markets in Europe (Food and Agriculture Organization, FAO, 2015). In Turkey, 240334 tones fish were hunted in 2015. On the basis this data, sea bass fish production amounts were 75164 tones as for The Information Source of Turkey (TUIK, 2015). [45, 46]. For this reason, fish scales of seabass have export capacity and importance in Turkey. In this context, eco-friendly fish scales have huge potential catalyst [45].

This study presents the production by the calcination of Seebass fish scales (Dicentrarchus Labrax), a new, low-cost, highly efficient heterogeneous catalyst for the successful use of the biodiesel synthesis of safflower oil as a transesterification catalyst. TGA, XRD, BET, SEM and FT-IR analysis were used to carry out the characterizations of the generated catalyst. From the XRD results, the best calcination temperature was determined as $1000^{\circ} \mathrm{C}$ and it was named as WFSC. The specific area, morphology, structure and weight loss of the novel WFSC was characterized by BET, SEM and FT-IR, respectively. Finally, the novel WFSC was used for biodiesel production with safflower oil and methanol. Fatty acid 
methyl esters (FAME) yield was calculated and evaluated. The yield was compared with traditional $\mathrm{KOH}$ catalyst.

\section{Experimental}

\subsection{Materials}

Safflower oil (Carthamus Tinctorius) has been supplied from Kayseri, in Turkey for biodiesel production. The fatty acid contents of safflower oil were determined by using GC and was shown in Table 3. Seabass (Dicentrarchus Labrax) fish scale was taken from fish market in Black Sea, Turkey. Methanol (>99\% purity) was purchased from Sigma Aldrich for transesterification reaction.

Table 3. The fatty acid contents of safflower oil

\begin{tabular}{|lll|}
\hline \multirow{3}{*}{ Safflower oil } & Compound & Fatty acid (\%) \\
\cline { 2 - 3 } & Oleic Acid (C18:1) & 17,99 \\
\cline { 2 - 3 } & Linoleic Acid (C18:2) & 72,61 \\
\cline { 2 - 3 } Palmitic Acid (C16:0) & 6,55 \\
\cline { 2 - 3 } Stearic Acid (C18:0) & 2,43 \\
\hline Arachidic Acid (C20:0) & 0,32 \\
\hline Myristic Acid (C14:0) & 0,09 \\
\hline
\end{tabular}

\subsection{Synthesis of the heterogeneous catalyst}

In this study, natural heterogeneous catalyst synthesized from seabass waste fish scales by using calcination method. For this purpose, firstly, waste fish scales were cleaned several times with deiyonized water to remove various dirtiness and other substances. The waste scales were dried in an oven for approximately 6 hours at $100{ }^{\circ} \mathrm{C}$. The dried scales were ground to a fine powder and calcined in a muffle furnace at different temperatures $\left(800-1000^{\circ} \mathrm{C}\right)$ for 2 hours. The novel waste seabass fish scale catalyst was named as WFSC. The WFSC was prepared with the following steps in Figure 3 . The best calcination temperature was determined by using XRD technique. The specific surface area of the novel WFSC was characterized by using BET technique. The morphology of the novel catalyst was defined by SEM. Additionally, Fourier Transform Infrared Spectroscopy (FT-IR) was realized to characterize the novel WFSC type. Finally, the novel synthesized catalysts were used for biodiesel production. FAME yield was calculated.

\section{Characterization Methods}

The produced novel WFSC properties were evaluated by using some characterization techniques. XRD patterns were obtained (Rigaku Smart Lab Co., Japan) using Cu K $\beta$ source equipped with an SC-70 
detector. The analysis was performed at $2 \Theta$ ranging from $2^{\circ}$ to $80^{\circ}$ at a scanning speed $1^{\circ} \mathrm{min}^{-1}$. The specific surface area and pore size of the novel WFSC was measured by BET method by using Quantachrome Autosorb model device. The surface morphology of the synthesized catalyst by using JEOL-SEM JSM 7001F model device has been used at $15 \mathrm{kV}$. The FT-IR spectra of the fish scales were obtained by Perkin Elmer Spectrum Two FT-IR spectrophotometer. Each spectrum was taken with in few seconds at the resolution of $4 \mathrm{~cm}^{-1}$ and 4 scans, in the region of $4000-650 \mathrm{~cm}^{-1}$ wavenumbers and the data were evaluated by using spectrum two software. Thermogravimetric analysis of the seabass fish (Dicentrarchus Labrax) scales (TGA) is conducted with the TA Instrument SDTQ600 analyzer. $10 \mathrm{mg}$ of sample was loaded into pans. The temperature ranges from 20 to $1000{ }^{\circ} \mathrm{C}$ with a heating rate of 15 ${ }^{\circ} \mathrm{C} / \mathrm{min}$ under nitrogen $\left(\mathrm{N}_{2}\right)$ atmosphere of $150 \mathrm{~mL} / \mathrm{min}$ to determine the thermal properties of seabass fish scales.

\subsection{Biodiesel Production}

In the present study, safflower oil was transesterificated with $25 \%$ (v/v oil) methanol (6:1 molar ratio) and $1 \%(\mathrm{~m} / \mathrm{m}$ oil) WFSC. Before the reaction, safflower oil was heated to remove water and humidity. The reaction was carried out nearly at $60^{\circ} \mathrm{C}$ for $1 \mathrm{hr}$ and $400 \mathrm{rpm}$ stirring speed. After the transesterification process, the methyl ester was then removed from the glycerol using a separation funnel. The methyl ester was washed introduced into a rotary evaporator to remove the excess water and methanol. Finally, the product was filtered by using filter paper. The yield of methyl ester conversion in this study was reported to be $85 \%$ from safflower oil, and the color of the final SME product was light yellow. For comparative purposes, the SME was produced with the traditional $\mathrm{KOH}$ catalyst. The yield was calculated $95 \%$ in the traditional process.

\section{Results And Discussion}

Fish scales (seabass) are composed of various matters such as water, organics, inorganics, minerals. The TGA was carried out for quantitative estimation of contents of fish scales. The effects of calcination conditions on weight change on fish scales were determined by the TGA method [31, 41,47]. The weight changes of fish scales were revealed in Figure 4 over the temperature range from 20 to $1000{ }^{\circ} \mathrm{C}$. The interpretation of TGA curve was explained in Table 4.

In Figure 4, the initial $8.02 \%$ weight loss corresponding to the temperature range of $20-150{ }^{\circ} \mathrm{C}$ indicating the evaporation of adsorbed water. occurred between 150 and $250{ }^{\circ} \mathrm{C}$ because of the loss of the lattice water. The weight loss of $45.60 \%$ resulted in the temperature range of $250-595{ }^{\circ} \mathrm{C}$, which can be attributed to fragmentation of macromolecules and loss of guanine and the other organic matters [31]. In additionally, $1.46 \%$ steady weight loss up to $1000{ }^{\circ} \mathrm{C}$ due to formation of gaseous elements. The hydroxyapatite (HAP) could be transformed into $\beta-\mathrm{Ca}_{3}\left(\mathrm{PO}_{4}\right)_{2}$ after $900{ }^{\circ} \mathrm{C}$ temperatures. The total weight loss was determined as $57.13 \%$ for calcined waste fish scale at $1000{ }^{\circ} \mathrm{C}$.

Table 4. The weight change of fish scale (Sea bass). 


\begin{tabular}{|llll|}
\hline Stage & Temperature Range $\left({ }^{\circ} \mathrm{C}\right)$ & $\begin{array}{l}\text { Weight Loss } \\
\%\end{array}$ & Causes \\
\hline 1 & $20-150$ & 8.02 & Evaporation of adsorbed water \\
\hline 2 & $150-250$ & 2.05 & Loss of the lattice water \\
\hline 3 & $250-595$ & 45.60 & Macromolecules fragmentation \\
\hline 4 & $595-1000$ & 1.46 & Formation of gaseous \\
\hline
\end{tabular}

Figure 5 shows the XRD patterns for the WFSC samples obtained over a calcination temperature range from 800 to $1000{ }^{\circ} \mathrm{C}$. In figure 5, small peaks of hydroxyapatite (HAP) at $800{ }^{\circ} \mathrm{C}$ [48]. Prominent peaks of HAP can be seen after $900{ }^{\circ} \mathrm{C}$ and the formation of $\beta-\mathrm{Ca}_{3}\left(\mathrm{PO}_{4}\right)_{2}$ conforming to transformation of HAP can be seen at $1000{ }^{\circ} \mathrm{C}$. The catalyst that produced at $1000^{\circ} \mathrm{C}$ act as a base catalyst. Narrow and highly intense peaks of the calcined waste fish scales referred the crystalline structure of the novel catalyst.

SEM micrograph (Figure 6) of catalyst samples exhibited the existence of circular holes distributed over the catalyst surface at calcination temperature of $1000^{\circ} \mathrm{C}$. As depicted in Figure 6.b, the internal layer of the WFSC (Fig. 3c) exhibited regular oval-shaped particles having tapered ends. Specific surface area of WFSC was determined $28 \mathrm{~m}^{2} / \mathrm{g}$ by BET technique.

Fourier transform infrared (FTIR) spectroscopy was utilized to define the different functional groups of HAP in waste fish scale before and after calcination process. Figure 7 exhibited the FTIR spectrum of HAP from fish scales (seabass) at 25 and $1000{ }^{\circ} \mathrm{C}$ temperatures. The indicator FTIR spectra show all characteristic peaks of HAP compound. The strong peak at around $1000-1100 \mathrm{~cm}^{-1}$ is due to asymmetric stretching mode of vibration for $\mathrm{PO}_{4}$ groups in HAP. As a major peak of phosphate group could be identified in the region between $1100-960 \mathrm{~cm}^{-1}$. The band at nearly $1637 \mathrm{~cm}^{-1}$ is due to overtone of $1016 \mathrm{~cm}^{-1}$ band. The presence of peak in the region $1637 \mathrm{~cm}^{-1}$ was due to absorbed carbon dioxide. The crystalline powder generates two characteristic stretching modes of $\mathrm{O}-\mathrm{H}$ bands at about $3307 \mathrm{~cm}^{-1}$. In the $1000{ }^{\circ} \mathrm{C}$ calcined samples, a new peak at $714 \mathrm{~cm}^{-1}$ (which not observed in the asreceived sample) is determined. This band is served to of $\mathrm{OH}-$ ion, which a description of the presence of structural $\mathrm{OH}^{-}$. The presence of the $\mathrm{OH}$ band confirmed the formation of characteristic apatite structure [49].

\section{Conclusions}

In the present study, it was depicted the prosperous application of calcined was fish scale (seabass) as an efficient heterogeneous catalyst for biodiesel production in transesterification of safflower oil. $\beta$ $\mathrm{Ca}_{3}\left(\mathrm{PO}_{4}\right)_{2}$ was generated from the hap in seabass fish scale with high temperatures with calcination process. The novel product could effectively catalyze the methanolysis of refined safflower oil to yield FAME (biodiesel) The best novel catalyst was prepared in $1000^{\circ} \mathrm{C}$. In addition, the results showed that it has reusability properties due to its' chemical and thermal stability. Therefore, it can be decribed as low- 
cost catalyst resource. The yield of methyl ester conversion in the study which catalysed by the WFSC was reported to be $85 \%$ from safflower oil. For comparative purposes, the SME was produced with the traditional $\mathrm{KOH}$ catalyst. The yield was calculated $95 \%$ in the traditional process. It was concluded that the novel WFSC was developed with a high specific surface area and basicity. The lower catalyst concentration acted in higher biodiesel yield. It is thought that the reusability of the catalyst and the recycling of waste fish scale will have a positive effect on the environment.

\section{Declarations}

\section{Acknowledgement}

The authors would like to thank to Dr. Nalan TÜRKÖZ KARAKULLUKÇU and Yunis GEDIK in KITAM, Ondokuz Mayis University, Samsun, Turkey, for the TGA and SEM analysis. This study was supported by Ondokuz Mayıs University with the number PYO.MUH.1904.21.009.

\section{Conflict of Interest Statement}

The authors have no conflicts of interest to declare. All co-authors have seen and agree with the contents of the manuscript and there is no financial interest to report. We certify that the submission is original work and is not under review at any other publication.

\section{References}

1. Ashok B, Nanthagopal K, Anand V et al (2019) Effects of $n$-octanol as a fuel blend with biodiesel on diesel engine characteristics. Fuel 235:363-373

2. Amin A (2019) Review of diesel production from renewable resources: catalysis, process kinetics and technologies. Ain Shams Eng J 10:821-839

3. Guloglu Y, Belkayalı N, Cesur İ, Bulut A (2018) Hidroelektrik Santrallerin Çevresel Etkilerinin Yargısal Denetimi. Akdeniz Üniversitesi Hukuk Fakültesi Derg 8:67-89

4. Özdemir Z, Mutlubaş H (2016) Biyodizel Üretim Yöntemleri ve Çevresel Etkileri. Kırklareli Üniversitesi. Mühendislik ve Fen Bilim Derg 2:129-143

5. Panwar NL, Kaushik SC, Kothari S (2011) Role of renewable energy sources in environmental protection: A review. Renew Sustain energy Rev 15:1513-1524

6. Jahirul MI, Brown RJ, Senadeera W et al (2013) The use of artificial neural networks for identifying sustainable biodiesel feedstocks. Energies. https://doi.org/10.3390/en6083764

7. Catarino M, Ramos M, Dias APS et al (2017) Calcium rich food wastes based catalysts for biodiesel production. Waste Biomass Valoriz 8:1699-1707

8. Jebaraj S, Iniyan S (2006) A review of energy models. Renew Sustain energy Rev 10:281-311

9. Peter S, Lehmann H (2008) Renewable Energy Outlook 2030. Energy Policy. https://doi.org/10.1007/s10098-007-0117-4 
10. Kralova I, Sjöblom J (2010) Biofuels-renewable energy sources: a review. J Dispers Sci Technol 31:409-425

11. Patel R, Patel S (2017) Renewable hydrogen production from butanol: a review. Clean Energy 1:90101

12. Borges ME, Díaz L (2012) Recent developments on heterogeneous catalysts for biodiesel production by oil esterification and transesterification reactions: A review. Renew. Sustain. Energy Rev

13. Antony Casmir Jayaseelan G, Anderson A, Poduva MK et al (2020) Synthesis and performances characteristics of biodiesel from animal fat. Mater Today Proc. https://doi.org/10.1016/j.matpr.2020.10.002

14. Vignesh P, Kumar ARP, Ganesh NS et al (2020) A review of conventional and renewable biodiesel production. Chinese J Chem Eng

15. Bolonio D, García-Martínez M-J, Ortega MF et al (2019) Fatty acid ethyl esters (FAEEs) obtained from grapeseed oil: A fully renewable biofuel. Renew Energy 132:278-283

16. Tabatabai B, Fathabad SG, Bonyi E et al (2019) Nanoparticle-mediated impact on growth and fatty acid methyl ester composition in the Cyanobacterium Fremyella diplosiphon. Bioenergy Res 12:409418

17. Razavi R, Bemani A, Baghban A et al (2019) An insight into the estimation of fatty acid methyl ester based biodiesel properties using a LSSVM model. Fuel 243:133-141

18. Xie W, Li H (2006) Alumina-supported potassium iodide as a heterogeneous catalyst for biodiesel production from soybean oil. J Mol Catal A Chem. https://doi.org/10.1016/j.molcata.2006.03.061

19. Sugözü İ, Cengiz Ö, Altun Ş (2010) The performance and emissions characteristics of a diesel engine fueled with biodiesel and diesel fuel. Uluslararası Mühendislik Araştırma ve Geliştirme Derg 2:50-53

20. Demirbas A (2009) Progress and recent trends in biodiesel fuels. Energy Convers Manag 50:14-34

21. Scott SA, Davey MP, Dennis JS et al (2010) Biodiesel from algae: challenges and prospects. Curr Opin Biotechnol 21:277-286

22. Yusuf N, Kamarudin SK, Yaakub Z (2011) Overview on the current trends in biodiesel production. Energy Convers Manag 52:2741-2751

23. Daud NM, Sheikh Abdullah SR, Abu Hasan H, Yaakob Z (2015) Production of biodiesel and its wastewater treatment technologies. Process Saf. Environ. Prot

24. Abbaszaadeh A, Ghobadian B, Omidkhah MR, Najafi G (2012) Current biodiesel production technologies: A comparative review. In: Energy Conversion and Management

25. Rezania S, Oryani B, Park J et al (2019) Review on transesterification of non-edible sources for biodiesel production with a focus on economic aspects, fuel properties and by-product applications. Energy Convers Manag 201:112155

26. Li H, Liu F, Ma X et al (2019) Catalytic performance of strontium oxide supported by MIL-100 (Fe) derivate as transesterification catalyst for biodiesel production. Energy Convers Manag 180:401-410 
27. Wei Z, Xu C, Li B (2009) Application of waste eggshell as low-cost solid catalyst for biodiesel production. Bioresour Technol 100:2883-2885

28. Nakatani N, Takamori H, Takeda K, Sakugawa H (2009) Transesterification of soybean oil using combusted oyster shell waste as a catalyst. Bioresour Technol. https://doi.org/10.1016/j.biortech.2008.09.007

29. Yang L, Zhang A, Zheng X (2009) Shrimp shell catalyst for biodiesel production. Energy Fuels 23:3859-3865

30. Viriya-empikul N, Krasae P, Puttasawat B et al (2010) Waste shells of mollusk and egg as biodiesel production catalysts. Bioresour Technol 101:3765-3767

31. Chakraborty R, Bepari S, Banerjee A (2011) Application of calcined waste fish (Labeo rohita) scale as low-cost heterogeneous catalyst for biodiesel synthesis. Bioresour Technol. https://doi.org/10.1016/j.biortech.2010.10.123

32. Ibarra-Gonzalez P, Rong B-G (2019) A review of the current state of biofuels production from lignocellulosic biomass using thermochemical conversion routes. Chinese $\mathrm{J}$ Chem Eng 27:15231535

33. Hamada M, Mikuni A (1990) X-ray diffraction analysis of sardine [Sardinops melanosticta] scale ash. Bull Japanese Soc Sci Fish

34. Imanaka T, Okamoto Y, Teranishi S (1972) The isomerization of propylene oxide on metal phosphate catalysts. Bull Chem Soc Jpn 45:1353-1357

35. Dijkstra AJ (2013) Interesterification. In: Edible Oil Processing from a Patent Perspective. Springer, pp 231-242

36. Bazi F, El Badaoui H, Sokori S et al (2006) Transesterification of methylbenzoate with alcohols catalyzed by natural phosphate. Synth Commun 36:1585-1592

37. Onozato H, Watabe N (1979) Studies on fish scale formation and resorption. Cell Tissue Res 201:409-422

38. Zylberberg L, Nicolas G (1982) Ultrastructure of scales in a teleost (Carassius auratus L.) after use of rapid freeze-fixation and freeze-substitution. Cell Tissue Res 223:349-367

39. Resende NS, Nele M, Salim VMM (2006) Effects of anion substitution on the acid properties of hydroxyapatite. Thermochim Acta 451:16-21

40. Sankar S, Sekar S, Mohan R et al (2008) Preparation and partial characterization of collagen sheet from fish (Lates calcarifer) scales. Int J Biol Macromol 42:6-9

41. Pati F, Adhikari B, Dhara $S$ (2010) Isolation and characterization of fish scale collagen of higher thermal stability. Bioresour Technol 101:3737-3742

42. Lorenzen K, Camp EV (2019) Density-dependence in the life history of fishes: when is a fish recruited? Fish Res 217:5-10

43. Loewen TN, Carriere B, Reist JD et al (2016) Linking physiology and biomineralization processes to ecological inferences on the life history of fishes. Comp Biochem Physiol Part A Mol Integr Physiol 
202:123-140

44. Gumisiriza R, Mshandete AM, Thomas MS et al (2009) Nile perch fish processing waste along Lake Victoria in East Africa: Auditing and characterization. African J Environ Sci Technol. https://doi.org/10.5897/AJEST08.149

45. Ozawa M, Kanahara S (2005) Removal of aqueous lead by fish-bone waste hydroxyapatite powder. J Mater Sci. https://doi.org/10.1007/s10853-005-6529-9

46. Alparslan Y (2017) Extraction, Characterization and Antimicrobial Activity of Hydroxyapatite from seabass and seabream scale. J Food Heal Sci. https://doi.org/10.3153/jfhs17012

47. Olson OP, Watabe N (1980) Studies on formation and resorption of fish scales. Cell Tissue Res 211:303-316

48. Varma K (2016) Morphology and dielectric properties of fish scales

49. Ahmed Y, El-sheikh S, Zaki ZI (2015) Changes in hydroxyapatite powder properties via heat treatment. https://doi.org/10.1007/s12034-015-1047-0

\section{Figures}

Transesterification Reaction
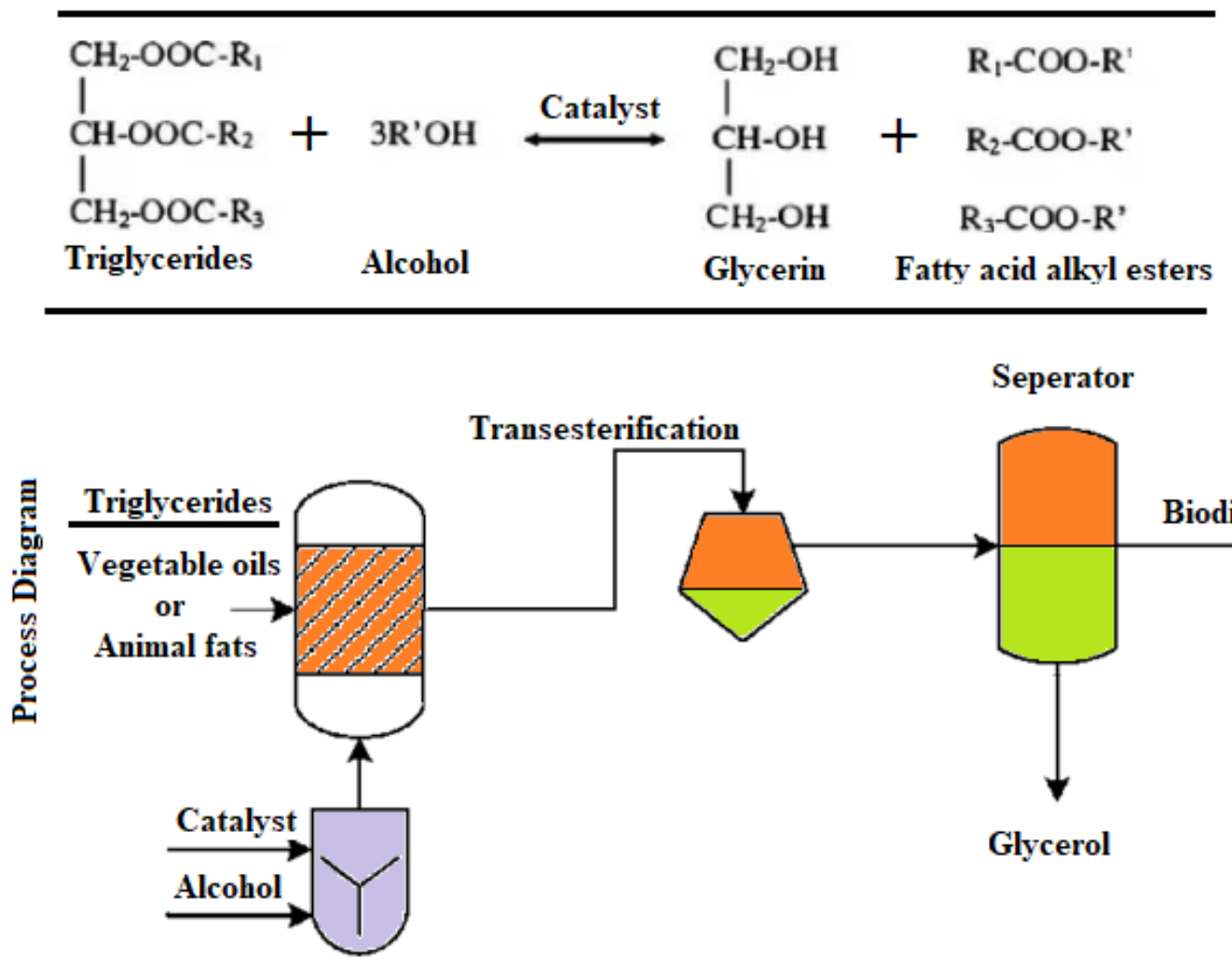

Seperator
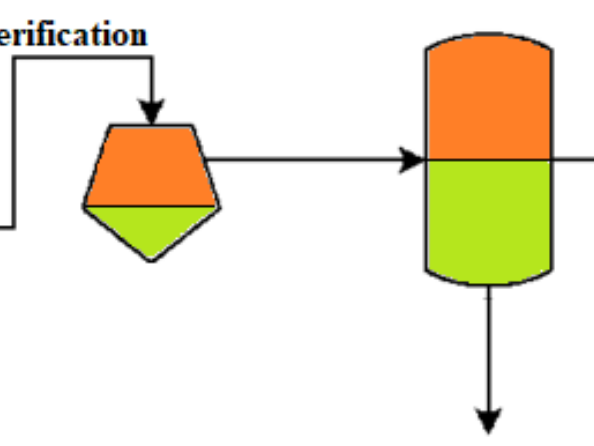

Glycerol

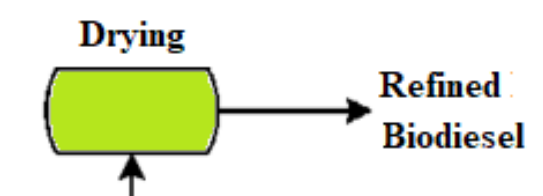

\section{Figure 1}

Transesterification reaction and process flow diagram and t of typical biodiesel production $[23,24]$. 


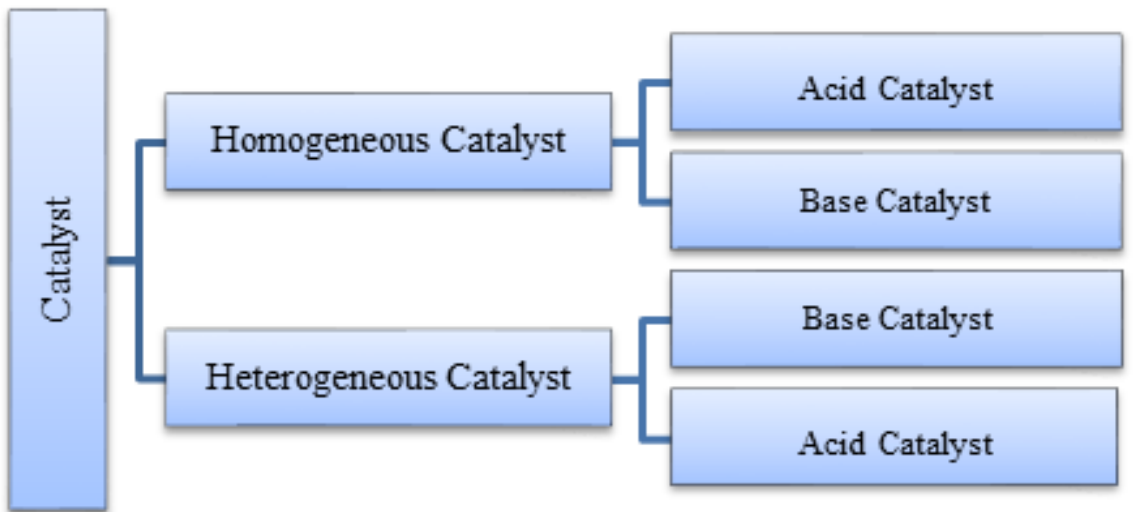

Figure 2

Classification on catalyst types [32].

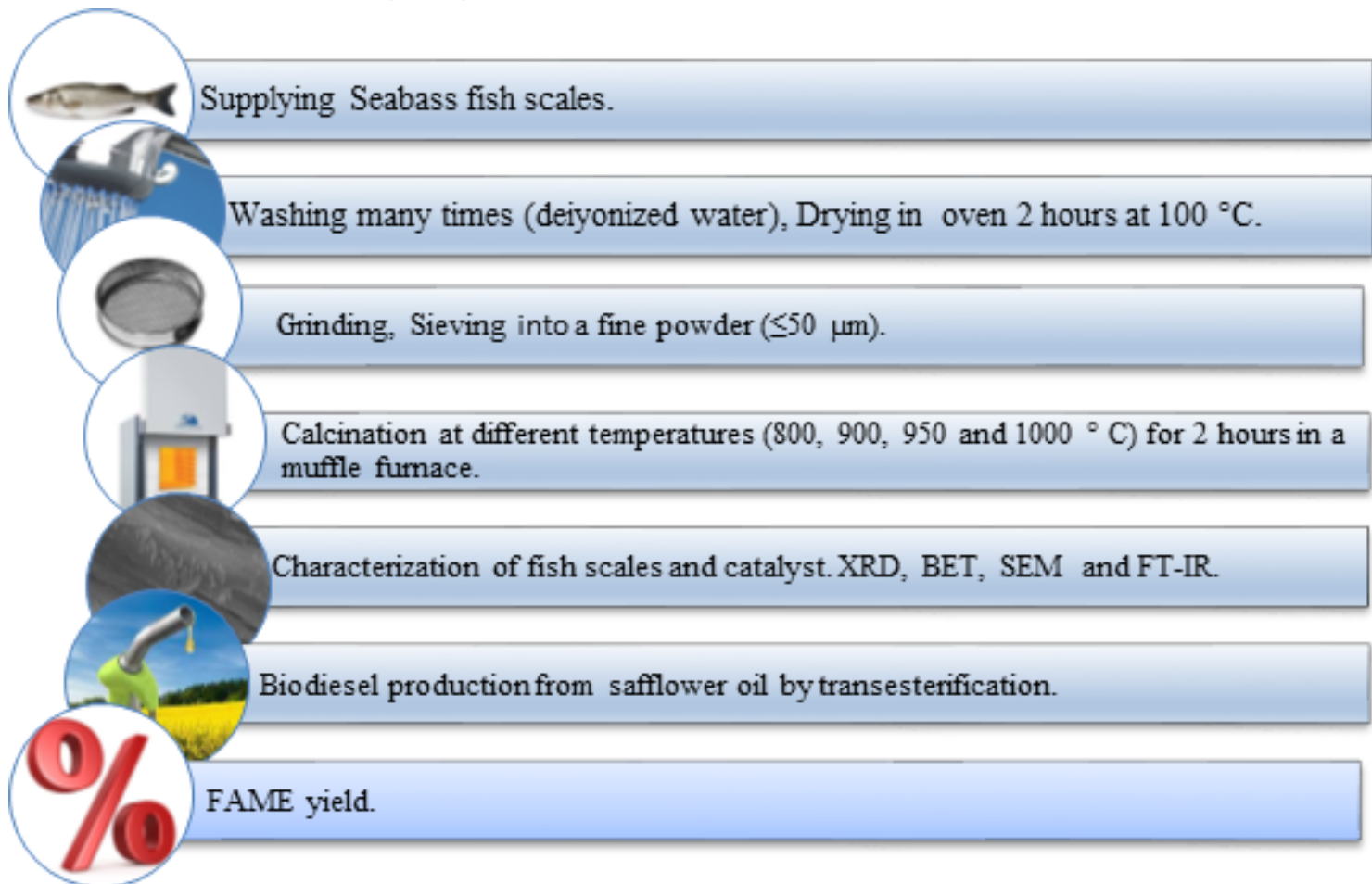

Figure 3

Preperation steps of heterogeneous catalsyt 


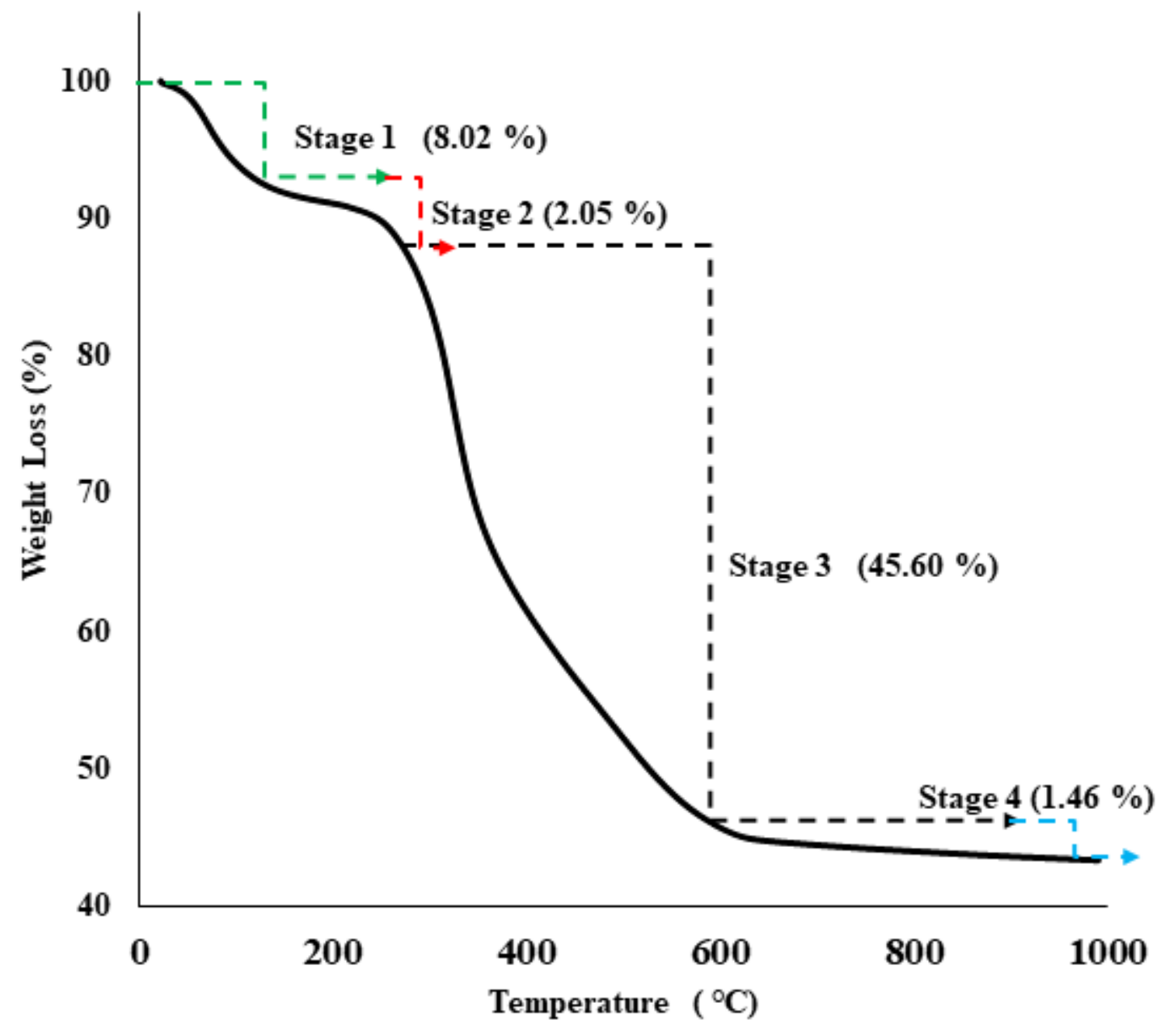

Figure 4

TGA curve of waste fish scale (seabass) between $20-1000{ }^{\circ} \mathrm{C}$ 

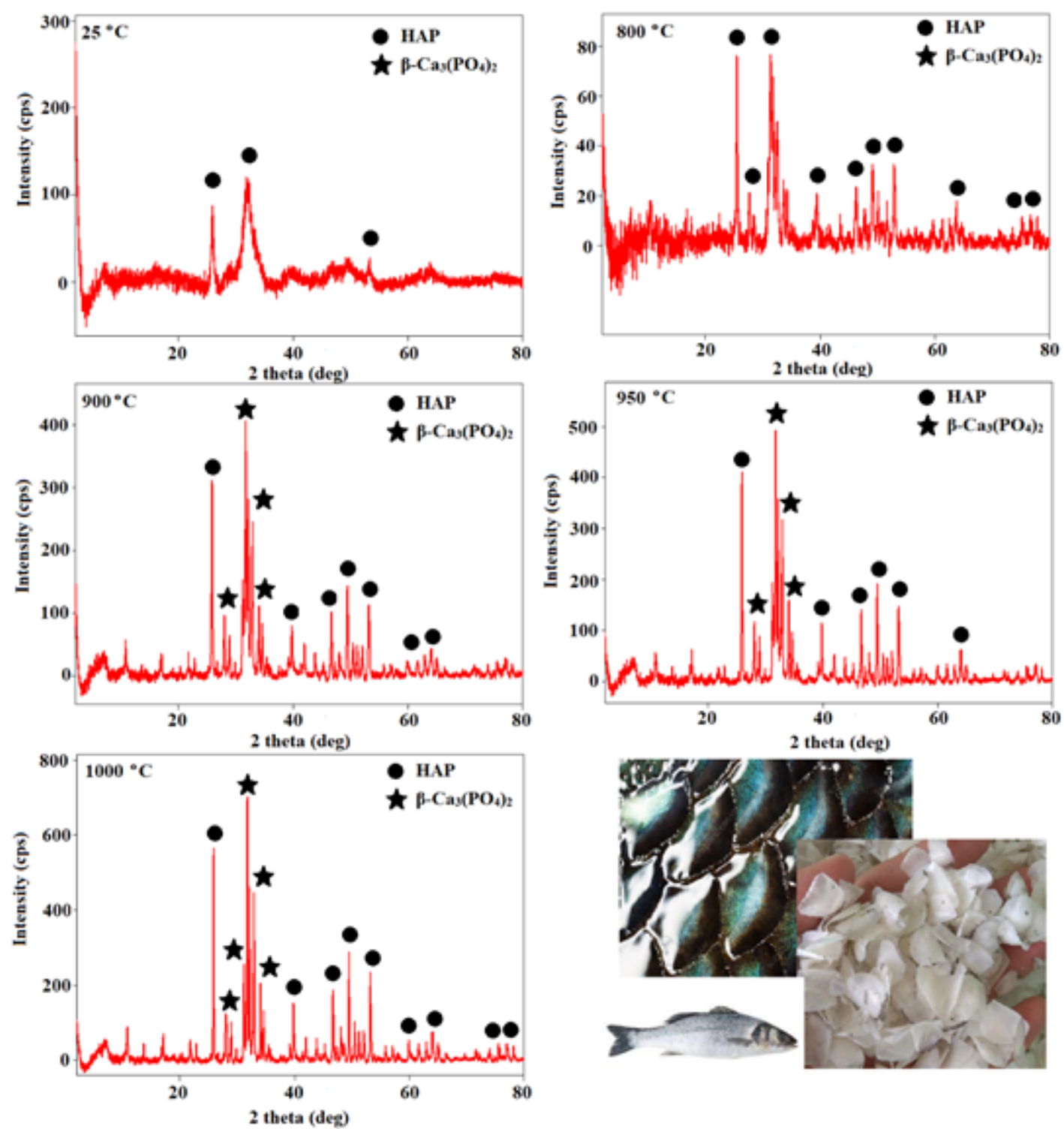

Figure 5

XRD patterns of waste Seabass (Dicentrarchus Labrax) fish scales derived catalysts by calcination at different temperatures $\left(800,900,950\right.$ and $\left.1000^{\circ} \mathrm{C}\right)$. 


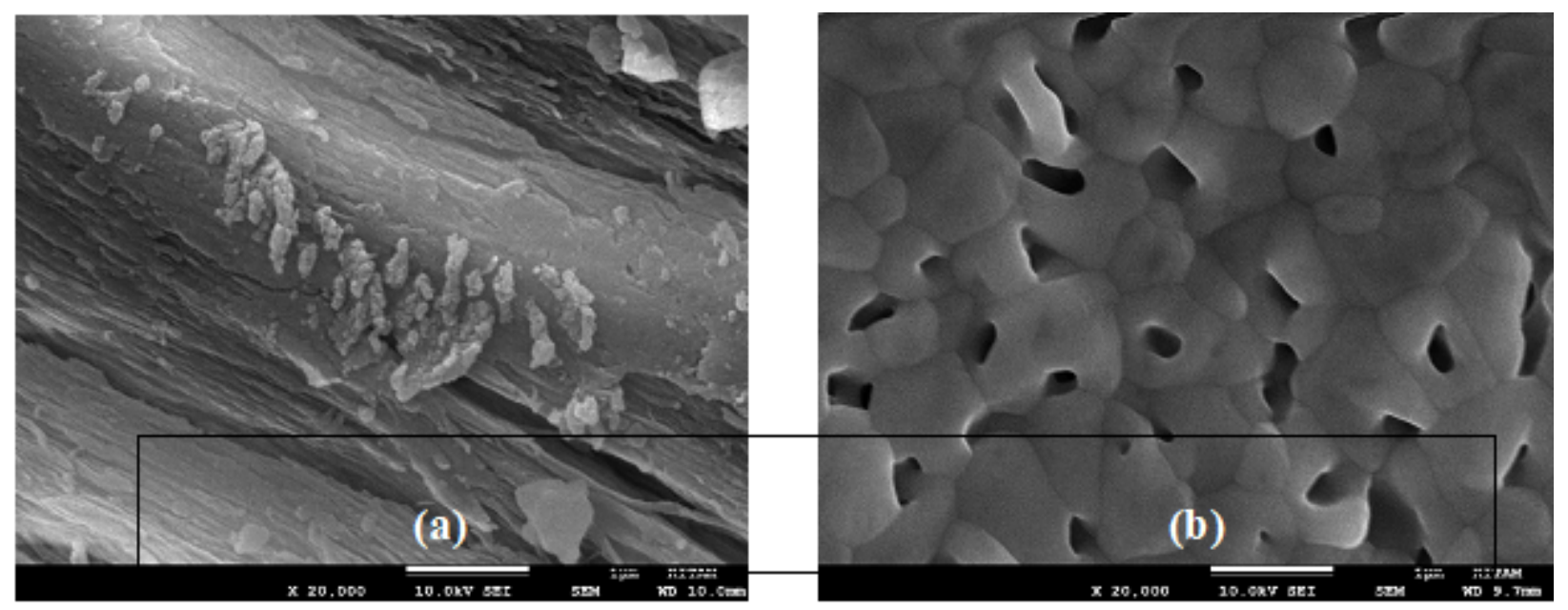

Figure 6

SEM images of the waste fish scale before and after calcination process a) $25^{\circ} \mathrm{C}$ (b) $1000{ }^{\circ} \mathrm{C}$

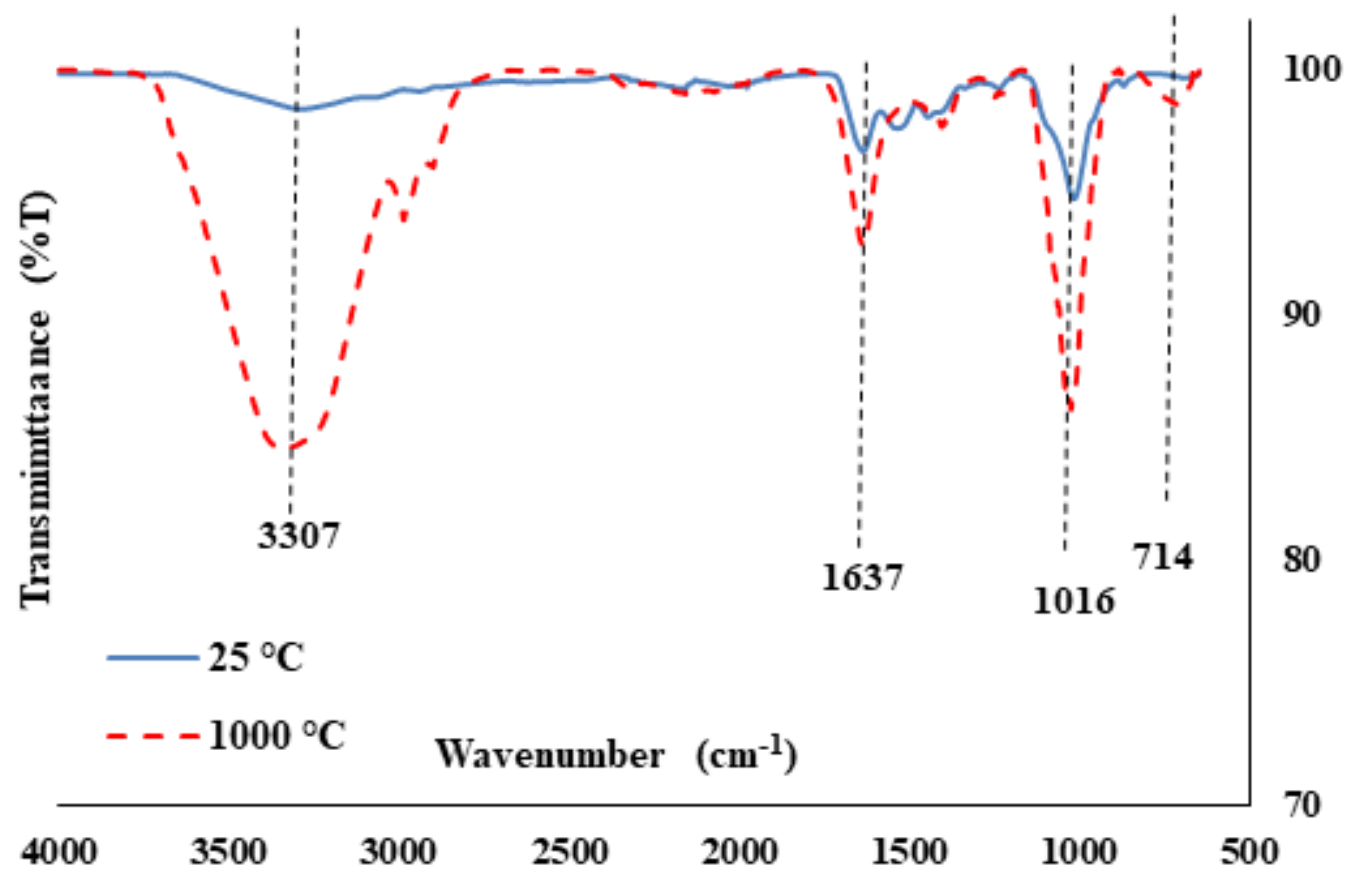

Figure 7

IR spectra of the waste fish scale before and after calcination process 